\title{
Balkanologie
}

Revue d'études pluridisciplinaires

Vol. $15 n^{\circ} 1 \mid 2020$

Mémoires performatives : faire des passés et des présents

\section{Remembering and being. The memories of communist life in a Turkish Muslim Roma community in Dobruja (Romania)}

Se souvenir et exister. Les mémoires de la vie sous le communisme dans une communauté rom musulmane turcophone de Dobrudja (Roumanie)

\section{Adriana Cupcea}

\section{OpenEdition}

\section{Journals}

\section{Electronic version}

URL: https://journals.openedition.org/balkanologie/2497

DOI: 10.4000/balkanologie.2497

ISSN: 1965-0582

\section{Publisher}

Association française d'études sur les Balkans (Afebalk)

\section{Electronic reference}

Adriana Cupcea, "Remembering and being. The memories of communist life in a Turkish Muslim Roma community in Dobruja (Romania)", Balkanologie [Online], Vol. 15 nº $^{\circ}$ | 2020, Online since 01 June 2020, connection on 05 August 2021. URL: http://journals.openedition.org/balkanologie/2497 ; DOI: https://doi.org/10.4000/balkanologie.2497

This text was automatically generated on 5 August 2021.

(c) Tous droits réservés 


\title{
Remembering and being. The memories of communist life in a Turkish Muslim Roma community in Dobruja (Romania)
}

\author{
Se souvenir et exister. Les mémoires de la vie sous le communisme dans une \\ communauté rom musulmane turcophone de Dobrudja (Roumanie)
}

Adriana Cupcea

1 My research is part of a direction regarding the current situation of the Turkish Muslim Roma in the national states of the Balkans, created after the fall of the Ottoman Empire, and it puts forward the description of a Muslim Roma Turkish-speaking community in a post-socialist city, Medgidia (Mecidiye), in the south-eastern part of Dobruja.

The Turkish ethnic group in Medgidia is characterized by internal diversity. It is composed of two subgroups. Turks, make up about $30-40 \%$ of the group while Turkishspeaking Muslim Roma, who declare themselves Turks and do not recognize affiliations to the Roma identity, represent the majority of the Turkish ethnic group. From the perspective of ethnic Romanians, most other ethnic groups in Medgidia, including the non-Roma Turks, are called Țigani turci (Turkish Gypsies) or more rarely Țigani musulmani (Muslim Gypsies). Given that most of them opt for Turkish identity both in official censuses and in their daily relations with the majority, in order to operate with a designation which covers the relation between self-image and the perception of others, I have opted to use the designation of Turkish Muslim Roma. Roma identity refers to the "Gypsy" identity on which the majority insists and to its rejection by the minority.

The differences between non-Roma Turks and Turkish Muslim Roma are mainly a matter of economic status and education. This invective, of Turkish Muslim Roma, thus marks a social category and not an ethnic category. The acquisition of a decent material situation involving either a job in the local community or resources accumulated from working abroad - together with education - mean for Turkish 
Muslim Roma the admittance and acceptance within the Turkish ethnic group. Since poverty and illiteracy are generally ascribed (by Turks, the Romanian majority, and other ethnic groups) to Gypsies, overcoming both statuses provides social mobility.

The specific objective of the presented research is two-fold. The first objective is to explore the intersection between memory and identity. The second objective is to identify the way in which the political, economic, and social changes of the communist period were reflected in the ethnic and religious identity structure of the Turkish Muslim Roma community of Medgidia.

Using as a framework the works of several authors influenced by symbolic interactionism ${ }^{1}$, I approached collective and personal identities as products of social interaction, which become present through narratives ${ }^{2}$. Approaching the narratives of memory as important acts of identity production, but absent archives or other written documents attesting to the creation of Medgidia's Turkish Muslim Roma community, I have chosen to use the only source to which I had access: life stories. These gave a detailed picture of the life of each interlocutor, while re-creating an overview of the origins and formation of the Medgidia community.

6 Using Maurice Halbwachs' theoretical framework of collective memory, I discuss individual memory as part of group memory. Halbwachs considers memories to be a social fact, since individuals accumulate memories as members of a given society. He claims that memory depends on "memory frames". These are social groups and institutions like the family, religion, and social class, which must feature in any recovery process and without which individual memories would be impossible. I have practically gathered and joined parts of memoirs and individual identities to determine the formation process and the course of a local community during the communist period. Exploring the memory of communism, life stories led my research towards the perspective of nostalgia. Nostalgia, understood as a type of memory, is a re-creation of the past that goes beyond the mere recovery, reaching political, ideological, socioeconomic, and personal dimensions.

7 I approached nostalgia from the perspective proposed by Maria Todorova and Zsuzsa Gille $^{4}$, who reject the idea that this feeling is a simple craving for the return to communism. They reaffirm Svetlana Boym's hypothesis that nostalgia is more related to present needs and to desires of the future. Therefore, nostalgia is not only about one temporal dimension, but three. It links the past, the present, and the future. It is the result of the association of these three dimensions at the individual level, and at the same time expresses the relation between individual biography and group biography, between personal memory and the collective one ${ }^{5}$.

Considering how nostalgia is manifest by my interlocutors, as an attempt to overcome personal and collective humiliation and to regain a sense of authenticity in the era of capitalism, I have used the concept of "reflective nostalgia" ${ }^{6}$. Reflective nostalgia operates with individual, selective memories. These often undermine the great national narratives and call absolute truth into doubt, revealing at the same time that longing and critical thinking are not opposed to one another, just as affective memories do not absolve one from compassion, judgment, or critical reflection. In this regard I have to mention that I placed the individual memories in my case study in the context of Zsuzsa Gille's statement that any positive mention of the socialist past is seen generally as ideologically suspect or unwholesome $\mathrm{e}^{7}$, and I subscribe to the clear statement that nostalgia does not indicate a desire to return to socialism or communism. Rather, 
nostalgia involves the goodness of everyday life that was permeated with solidarities, family outings, social gatherings, and a meaningful sense of life. Not all positive socialist memories imply an ideological content. At the same time, nostalgia offers a powerful critical commentary on the post-socialist capitalist cultures that brought insecurity, unemployment, and new ethical values. Given the fragmented, selective way of remembering, I can state that even the discourses of origins are affected by reflective nostalgia, generating trajectories of the past that are kept in the minds and felt in the hearts of the Turkish Muslim Roma in Medgidia, as pieces inherited from their elders. In some cases, I witnessed positive pre-communist references to the Ottoman period of Dobruja, as well. These references are influenced by the mainstream historical narrative of the Turkish ethnic group. They could be interpreted as unleashed, long-buried traces of an Ottoman nostalgia, and maybe as indicators of a restorative nostalgia, a component of the post-1990 identity discourse of the Turkish group in Dobruja which legitimizes their historical roots and positions the group as heirs of the Ottoman Empire in the region.

Interviews conducted in October 2015 in Medgidia follow the life-history approach and consider oral history an essential resource for exploring the discourse of origins alongside the subjective nature of life under socialism ${ }^{8}$. Such an approach is necessary to understand the community's formation, its social and economic peculiarities ${ }^{9}$, and the changes that occurred in its ethnic and religious identity during this period. The collective memory regarding general life under communism cannot be ignored, especially since most Turkish Muslim Roma people in this case study feel nostalgic for an economic system perceived as providing more material security despite political disadvantages. In this context, each life history becomes also an individual version of the past that explains and compensates the present ${ }^{10}$.

Although data and events are presented as historical landmarks, they are most often chronologically approximated in life histories. These are rather focused on everyday practices, on survival strategies and tactics in communism. Thus, their representation of the past reveals, on the one hand, the urban sedimentation process of a community in communism, it shows the identity dynamics marked by the life of the "new socialist man" and, on the other hand it contradicts the classical classifications of the system. Thus, the equalization of socialism with economic shortage is replaced in some cases with explanations regarding the ways of managing material insufficiencies.

11 The interviews that underpin the research were conducted with members of five families of Turkish Muslim Roma, aged between 42 and 73 years. They were inhabitants of three of the four neighbourhoods in which Muslim Roma live: Cement (a.k.a. Ali Baba), Silos, and White House. With a few exceptions, they are retirees from the two main factories of the communist period - IMUM, focused on the repair and production of heavy machinery, and the Cement Factory. IMUM is now closed; the Cement Factory is privatized and retains a small number of employees. The living space of the Turkish Muslim Roma consists mainly of the apartments, located in blocks built during the communist period, which were distributed to them as a result of their worker status in the main factories. This is especially true for those located in the Cement and White House neighbourhoods. Those in the Ali Baba neighbourhood also live in houses built on lands received from the communist state.

Even among the interviewees there are some exceptions to the general pattern. A special case is $\mathrm{H}$., aged 52 . H. lives in one of the barracks which belonged to the foreign 
workers who during the communist period worked at CFR (Romanian Railway State Company) and at the Danube-Black Sea Channel. After 1990, when the workers returned to their places of origin, the barracks were re-inhabited by others.

Movement of individual family members is high. Currently $\mathrm{H}$. is begging in one of the countries of Western Europe. The children of factory retirees migrated to countries such as Germany or Spain because the local labour market offers them no alternatives. A partial exception is the M. family from the Cement neighbourhood. Here, the mother works as a cleaning lady at one of the local public institutions. Of her two daughters, one is financially supported by a husband working abroad, but the second has a husband who occupies a job within the representative organization of the Turkish minority.

\section{Turkish Muslim Roma in Dobruja}

The present work on the Turkish Muslim Roma community in Medgidia must be addressed in the broader historical, geographical, and cultural context of the Dobruja region. Taking into account five centuries of evolution under the Ottoman administration, Dobruja presents alongside the common features of the border regions, characteristics that link it to its Ottoman imperial heritage, especially in its demographic and cultural composition ${ }^{11}$. The province was taken over by Ottoman administration in the fifteenth century. Over the next hundreds of years, an intense military colonization by Turks and Tatars of Islamic religion from Crimea and Asia Minor followed, setting a defining stamp on Dobruja's demographics and cultural characteristics. Generally, the colonization by Turks and Tatars is known, but I can presume that there were also Turkish Muslim Roma who came because elsewhere in the Balkans Turkish Muslim Roma came with the advancement of the Ottoman Empire in the fourteenth and fifteenth centuries, either as auxiliaries or craftsmen in the Ottoman army. Others settled here in the Balkans, including in Dobruja, before the Ottoman period, in the ninth through eleventh centuries, adopting the Islamic religion after their integration into Muslim society ${ }^{12}$.

They have learned to a large extent the dominant language, Turkish, assuming in parallel the Turkish identity, to the detriment of their own identity. Marushiakova and Popov point out these processes being à la longue durée, present since the Ottoman and extended also after the creation of the Balkan national states, highlighting the gradual correlation or overlap between the religious and ethnic identity of the Muslim Roma, underscored by the addition of the term "Turkish", which implies belonging to the Islamic religion and vice versa ${ }^{13}$.

In the Balkans, especially in Greece, Albania, Bosnia, Macedonia, Bulgaria, and Romania, there are communities that are identified by the local majority populations as Turkish Gypsies (turski tsigani, turkogifti, Țigani turci) ${ }^{14}$. Another term used for the general designation of Muslim Roma communities in former Ottoman territories in the Balkans is that of Xoraxane, which means Turkish Roma in Romani. In the case of the Turkish Muslim Roma community in Dobruja, no one uses the term Xoraxane. Among locals of Dobruja, the term is recognized only by older people, who define it as an old term, now lost. Its past use to designate Turkish Muslim Roma is difficult for them to place chronologically, but ranges between the early twentieth century and the early years of communism. 

outlined, was one of the most important urban centres of the coastal area since the Ottoman period of Dobruja, with cultural and urban features specific to the Ottoman Balkans. Medgidia was known during this period as a settlement with a majority Muslim population ${ }^{26}$ and as a fiefdom of the Tatars, established in the wake of the Crimean War of 1853-185627. Nevertheless, after 1878, Medgidia maintained its multiethnic and multi-cultural footprint of the Ottoman period, with Turks and Tatars living here as well other ethnic groups such as Greeks, Armenians, Roma, and Russians. 

number of Tatars oscillated at the turn of the twentieth century between 5,000 and 6,000 . The number recorded in the 1930 census, fell to 1,286 , but had an upward trend throughout the communist period (2,203 in 1956, 3,086 in 1966, and 3,977 in 1977) ${ }^{29}$.

At the same time, at the beginning of the twentieth century, the number of Turks was much lower than that of the Tatars, but in a continuous increase, reaching 298 in 1889 and 1,080 in 1902. After the fall in the 1930 and 1956 censuses, 606 and 486 respectively, the upward trend is resumed during the communist period, with Turkey being the ethnic group with the biggest demographic increase since the 1960s (1,456 in 1966 and 2,615 in 1977). At the first census of the post-communist period in 1992, Tatars registered 4,020, and the Turks 3,977, but their numbers began to decrease again because of emigration. Thus, in 2011, the number of Turks reached 3,340, slightly exceeding that of the Tatars, registered as 3,211 people $^{30}$.

According to the census data of 1930, only $28 \%$ of the population of Dobruja was urban With a consistent increase taking place after 1948, Medgidia was among the cities in Dobruja which at the beginning of the communist period recorded the biggest increases in urbanization, along with ConstanȚa, Tulcea, and Mangalia ${ }^{31}$.

Socialist industrialization has brought profound changes to space, demographic structure, and Medgidia's local society. As in other cases, the expansion of the urban centre has been linked to the opening of new factories, which attracted the rural population around town to take up jobs. Medgidia has been customized by the construction of the Danube-Black Sea Channel, which put its mark on the demographic evolution and on the local industry, which was shaped according to the needs imposed by the construction of the Channel. The main factories were IMUM, focused on the repair and production of heavy machinery, and the Cement Factory. Both were built between 1949-1951 and together absorbed most of the local labour force. In 1989, at the fall of communism, each of these two major industrial plants had some 6,000-7,000 employees.

From a demographic perspective, during the communist period a constant increase of the population can be observed. The most consistent influx was recorded between 1949-1953, during the first stage of construction of the Danube-Black Sea Channel. In 1949, there were 6,824 inhabitants, of which 2,500 had a floating visa for Medgidia. In 1953, when the first stage was completed, there were already 13,500 inhabitants. The inhabitants with a floating visa worked most likely at the Channel, later settling in Medgidia. After the completion of the first stage of Channel construction, most were then hired by IMUM and the Cement Factory ${ }^{32}$ (Ilie 2008: 126), by the Medgidia Collective Agricultural Holdings (G.A.C.), or by the limestone factory, CAOLINUL. The most prominent demographic growth took place between 1949 and 1977 when the population increased from 6,824 in 1949 to 17,943 in 1956, 27,981 in 1966, and reached 40,328 in $1977^{33}$.

Migration to urban areas was specific to the entire area of the Carasu Corridor, due, as I said, mainly to Channel works carried out in this geographical area. Many of the inhabitants of the villages in the area emigrated to the nearby settlements, of which Medgidia had the highest absorption capacity due to the industrial sector developed there. In the period 1977-1985, Medgidia's population increased to 47,830 inhabitants $^{34}$. This period overlapped partially with the second phase of the Channel construction. 

rhythm fell into a continuous downward slope. This was again due to the migration of the labour force, which had no more means of income after the factories were dismantled. Migration was first directed to the states of the former Yugoslavia and Turkey. After Romania's integration into the EU, migration turned to the Western states. After 2007, the rate of decline was more accelerated, so that between 2002-2011, the population decreased from $43,841^{36}$ to 39,780 inhabitants ${ }^{37}$.

\section{Turkish Muslim Roma in Medgidia}

As noted above, the formation of the Turkish Muslim Roma community in Medgidia is not explicitly documented. During archival documentation at the County Directorate of the Archives in ConstanȚa I identified files about Medgidia during the communist period $^{38}$, such as those produced by the city administration or those from the DanubeBlack Sea Channel during its two stages of construction. These documents rarely contain information on the ethnicity of the inhabitants of Medgidia or on the ethnicity of the Danube-Black Sea Channel workers. Turkish Muslim Roma can be identified in the documents of the Medgidia City Hall Fund in the 1960s, according to their specific names ${ }^{39}$, as owners of real estate in the current neighbourhood of Ali Baba. Following the same criterion of the frequent names in the Turkish Muslim Roma community, they can be more often identified in the 1980s as part of in-service training courses, in the documents relating to the second phase of the Channel construction, 1976-1984. For example, some names likely to belong to Turkish Muslim Roma in the Headquarters of the Danube-Black Sea Channel Fund 1/1983 are: șaban Rizea ${ }^{40}$, Ramazan Nerman ${ }^{41}$, Iomer Talip ${ }^{42}$, and Ibram Ridvan ${ }^{43}$.

The only information related to the creation of the community in Medgidia comes from oral sources and specifically from interviews with community members, elder inhabitants of Medgidia, and representatives of local authorities. They indicate that the Turkish Muslim Roma migrated to Medgidia from rural areas of southern Dobruja during the 1950s and 1960s, settling predominantly in the Cement neighbourhood, where they were housed as employees of the Cement Factory. The pejorative name given to the Cement neighbourhood, Ali Baba, points to one of the Scheherazade tales, Ali Baba and the 40 Thieves, and refers to the perception of Turkish Muslim Roma in the collective mentality of the local community. Although presently Ali Baba is quasiknown in the Dobruja region as an exclusively Turkish Muslim Roma neighbourhood, they live compactly also in other areas of the town, such as Silozuri (Silos), in the barracks which belonged to the CFR and Channel workers and who after 1990 returned home or went in other parts of the country. They live also in Ostrov district (known also as Catanga), in the apartments distributed during the communist period and which, due to the deindustrialisation and decrease of the local living standards are in a profound state of degradation. They also live compactly in two blocks, distributed by the town hall as social houses around 1980 and located close to a bridge, known in the local language as the White House, due to their white color.

31 The local Turkish Muslim Roma leader, who is President of the Turkish Democratic Union in Medgidia, estimates a total of 7,000 Turkish Muslim Roma, while the Roma consultant at the Medgidia City Hall and the Tatar History Professor E. G. say that their

Balkanologie, Vol. $15 n^{\circ} 1$ | 2020 
approximate number is of 4,000 and 5,000 people, approximately equal to the number Tatars.

It is not possible, as in the case of other ethnic and confessional communities, to estimate the size of the community on the basis of registers kept by religious institutions. For Muslims in Dobruja, there is no custom to keep a written record of the number of believers. Moreover, the accounts of the Imams in Medgidia, even of the elders, are limited to the mentioning of an equal number of Turkish Muslim Roma with the number of Tatars. Together with other interlocutors, they also report a share of $40 \%$ to $60 \%$, between the Turks and the Turkish Muslim Roma who declare themselves as Turks. They consider that achieving an equal number of Tatars and Turks in Medgidia is an irreversible consequence of the communist period, and more exactly of the absorption of the Turkish Muslim Roma from the villages of southern Dobruja into the industrial labour force.

\section{Memory of community origins}

The memory of the origins of the community is found as part of the family trails transmitted from generation to generation, and it actually indicates what was transmitted within each family about its own roots. Thus we observe how individual stories are mental maps of family itineraries ${ }^{44}$, which can be combined to reconstruct the history of the Turkish Muslim Roma community in Medgidia.

The history of most Turkish Muslim Roma families starts with emigration at the beginning of the 1950s, from Bulgaria to Romania and into the villages of Dobruja. The reasons for the emigration of parents, grandparents, or great-grandparents are not clear every time, but where they have been passed between generations, they refer to the anti-Islamic propaganda of the Bulgarian communist regime, which started in the 1950s and continued in the 1970-1980s with an aggressive ethnic and cultural assimilation process of the Turks in Bulgaria ${ }^{45}$. In the M. family of Ali Baba, for example, L., aged 39, remembers her grandmother's stories. L.'s mother and her sister S., L's now-72-year-old aunt, were children when they left Cadrilater to come to Dobruja. L.'s account rationalizes the experiences of previous generations without resorting to the memory of personal experience.

Our (grand)parents were born and raised in Bulgaria, but the Bulgarians became wicked at that time, so they were no longer allowed to keep their religion, to make weddings in our tongue, it was not possible to baptize children in our custom, they were not allowed to do any Muslim things, going to the Friday prayer, to keep the bayrams ${ }^{46} . .$. Who managed to escape..... ${ }^{47}$

Grandmother was telling us that whole communities left with the boat. People took some things in a bag and left the lights on so the communists would not realize that they left and put their children in boats and passed the Borcea Arm (of the Danube) to get to this side. And from there they spread all over. When they came here, the state gave them houses and they paid a rent to the state for the nationalized houses in which they stayed.... ${ }^{48}$

Most of the time, the life story begins from the origin village within Dobruja. Personal histories overlap on geographic itineraries with intermediate points, which finally stabilize around the urban centre of 1960s-1970s socialist Medgidia, in its full period of industrialization: Pietreni (village)-Medgidia (town) ${ }^{49}$; Călărași (town)-Pietreni (village)-Castelu (village)-Medgidia (town) ${ }^{50}$; Pietreni (village)-Medgidia (town) ${ }^{51}$; Tudor 
Vladimirescu (village)-Băneasa ${ }^{52}$ (village)-Medgidia (town) ${ }^{53}$; Dobromir (village)Medgidia $^{54}$; Peștera (village)-Medgidia (town) ${ }^{55}$. opportunities, the shift from the agrarian to the industrial profile of the economy, and implicitly, the demographic movement from the village to the city, against the background of the industrialization and urbanization processes started under Gheorghe Dej's dictatorship. Ideologically motivated, the industrialization process and its main consequence, the development of urban areas, had to support the efforts of the state to transform society. In this context, the city had to materialize the ideal of the socialist society and its inhabitant, the worker, as the new socialist $\operatorname{man}^{56}$. Thus, viewed in the context of that period, the Turkish Muslim Roma itineraries in Medgidia illustrate the classical trajectories of the members of the working class in communist socialism. They move from the status of farmers to that of the urban working class, motivated by the increasing differences between urban and rural living standards, by the desire to avoid the effects of collectivization that have affected the rural world, and (not least) attracted by wages in the industrial sector, specific to urban areas. the Turkish ethnic group in which Turkey is perceived as the territory of origin, the historical root of a mobility path extended deep in the times of the Ottoman administration of Dobruja: "We came from Bulgaria, our parents came from Bulgaria and they have their origins in Turkey, and Dobruja belonged to the Turks." ${ }^{57}$

This type of information appears in the case of those who are closer to the Turkish Democratic Union of Romania, by their personal involvement in various activities or positions within the union (branch president, secretary). Through them takes place the contact of other members of their families with this kind of narrative, assimilated from the specifics of the union's activities. Such narratives combine an oral tradition transmitted from the previous generations with union-circulated information about the history of the Turkish ethnic group. This combination facilitates certain types of deductions on historical affiliations and their placement over time. "They were born and raised there (Pietreni), our grandparents have remained with those wars which lasted for about 500 years, Dobruja was occupied by the Turks here ... and I think their roots are in that time, because here are Turkish villages around, with Turkish names ... Baspınar, Izvoru (i.e. Mamutkuyusu)." 58

\section{Ethnicity and religion during the communist period. Turks, Muslims, or working class?}

The elements that the Turkish Muslim Roma from Medgidia used to connect with their ethnic and religious identity during the communist period are difficult to identify at first glance. This is so because self-identification as well as the general perception of the society were obviously influenced by the politics conducted by the communist state. The creation of the single working people meant a homogenization of the society and an integration of all citizens without regards for ethnicity in the egalitarian communist society. This meant homogenization, even assimilation, both social and national ${ }^{59}$. Thus, both at the individual as well as at the community level, the interviews conducted with the members of the Turkish Muslim Roma community show a

Balkanologie, Vol. $15 n^{\circ} 1$ | 2020 
detachment from ethnic and religious membership during the communist period. This is a result of, and is also motivated by, their integration in the structures of the new working class. Their membership in the working class defined their role in society, offered them financial security and dignity, and led to a prevalence of that social identity (as worker) in the process of self-identification and relation to the society at large. Their main concerns during the communist period were mobility, adaptation, and integration within the socialist society. Ethnicity and religion represented at this point in time were considered given elements of their identity; they were accepted from the start and were not considered to affect their immediate present or immediate needs.

Everyone left the countryside. They worked at Cement and at IMUM, they went to work in these factories, they did not want to sit in the village anymore. You saw how difficult life is in the countryside, but in the cities it is better. They took a house and moved here all the way. There were no houses before in this area and the city hall gave them places to build their homes. Here in the back were the studios from Cement. Each factory had several blocks. They had young people who were coming from the villages around and looking for work. They were giving them food, lodging, everything needed.... ${ }^{60}$

References to ethnic membership appear mostly when the first decades of the communist period are remembered - the decades spent in Dobruja villages, before migrating to the Medgidia industrial centre in the 1960s-1970s. The usage of the maternal language in daily life is a trait present in rural life, in the villages of origin, and is connected with the youth of the older interlocutors. For example, U. L. remembers that the Turkish language was part of the continuous social contact between Turks, Tatars, and Romanians. The knowledge of the Turkish language, also among Romanians living in Dobruja's rural areas at the beginning of the twentieth century is a recurring element in the recollections of many of those interviewed.

Language was the element of ethnic identity that received the greatest influence from the changes that took place in socialist society. Migration from the village towards the city, and the settlement of Turkish Muslim Roma in the working-class neighbourhoods of Medgidia, meant a distancing from the community connections typical for the rural world that represented the social nucleus for transmitting Turkish as a maternal language, as well as religious traditions and practices. After settling in Medgidia, the Turkish language became mostly a means of communicating inside the family and at the occasional meetings between members of the community at occasions like baptisms, weddings, or funerals. This conclusion is drawn from what the interlocutors related.

Outside the house, as was our case, we worked and we spoke Romanian. I speak Turkish only so-so, because I needed Turkish not to starve among the Turks, while I was working there. D. is not speaking, she only understands; my older sister is speaking Turkish, she's married with a Turk and she spoke in the house of her mother-in-law and she speaks very well; another sister is married to a Romanian and she doesn't know Turkish at all. But I have my aunts, my mother's sisters. They speak only Turkish because they stayed only at home, and their daughters, my cousins, are speaking very well because they spoke it a lot in the house ${ }^{61}$.

Although religious freedom was guaranteed during the communist period, the regime practically conducted an atheist policy to reduce the role of religion, and persistently tried to restrict religious activities to a strict liturgical role ${ }^{62}$. This is true for all religious cults, including the Muslim religion. This policy was put in practice through 
indirect methods of inhibiting religious manifestations, and in time led to a social secularization process defined mostly by a diminishing religious practice and a confinement of religion to one's private life $^{63}$. In this sense, the testimonials offered by the members of society suggest a gradual separation from spiritual life, as a result of their professional and social integration in the socialist society. The testimonials exclude, however, any direct persecution conducted by the communist regime on account of their being Muslim. Their new status as members of the working class meant they followed a program that regulated their daily lives in a manner not compatible with the religious practices of Islam. They emphasize the organization of religious services at the mosque every Friday, while also confirming the impossibility of taking part because they overlapped with working schedules. In practice this meant that in the 1960s and 1970s most of the community missed Friday services. Kurban Bayram ${ }^{64}$ and Ramazan Bayram ${ }^{65}$ are presented as the main religious holidays, respected by all members of the community by taking part in the religious services organized at the mosque.

It is often admitted in social representations that it is a man's responsibility to go to the mosque on Fridays. He practically represents the interface between the family and the community's religious life. In the context of the small working Muslim community from Medgidia, however, the women were the ones who assumed religion as a preoccupation during the communist period. Given that most of the Turkish Muslim Roma families in Medgidia lived as a nuclear family of parents and children, with the grandparents living in the countryside, the women ensured the survival of the religious sentiment. This was especially valid in situations where the father, as the male head of family, provided economic support and the mother stayed at home and took care exclusively of the house and family. Thus, the prayers and fasting (at Ramazan) was undertaken by wives, first of all because they enjoyed the time needed to dedicate themselves to these practices that took place at home. The family coagulated around the woman who also became transmitter of religious feeling and maternal language. The rule, of course, was by no means exclusive. There were men inclined towards religion. Although such men could not include religious practice in their daily schedule, they kept religion as a personal practice, reserved for moments when they had time to read their prayers. For example, L.M. recounts the prayer books in Turkish that belonged to her father, part of them inherited from the grandparents, while others were brought by relatives from Turkey during the visits allowed every two years by the regime; her father, a religious man, read them regularly.

On the whole, we can state that although socialist modernization and the atheist policy led to a secularization of society in terms of diminishing religious practice, it more accurately led to a relocation of religion from the public space, accompanied by a domestication and an individualization of faith ${ }^{66}$. In the cases where religion is still a concern, its only area of manifestation is a private one.

The general view that the Turkish Muslim Roma share about the practice of Islam in the communist period is a positive one. They consider themselves to have enjoyed a relative freedom of worship without any direct repercussions from the regime. The ascertainment is always followed by the comparison of their situation with that experienced by Bulgarian Muslims. The forbidding of Turkish names and of practising the sunnet (the circumcision of boys), and the stories about Bulgarian Muslims who crossed over to Romania across the Borcea Arm in order to circumcise their boys are 
arguments for stating that followers of Islam enjoyed a protected status during the Romanian communist regime, both in relation to the authorities and in living alongside their Christian neighbours.

Ceaușescu forbid us nothing. It was said that the Bulgarians (Muslims) were forced to become Orthodox, that they killed the child if there was a baptism, and we were also afraid Ceaușescu might do this, but he did not. We enjoyed freedom here, we could have a baptism and a wedding on the street, we went to the mayor's office and obtained an approval that the street took care of things, and also from the neighbours that we did not bother them. And we raised the tent in the middle of the street.

When my older sister got married we made such a ruckus here on the street... the Romanians are used to us here....67

One story that resides in the collective memory, transmitted through those who worked at the Channel, confirms the perception about the tolerant attitude that the communist regime had towards the Muslim community because of the relations developed between the Romanian communist state and the Muslim Arab states.

Ceaușescu had a very good relationship with the Muslims in general, since he went to his Arabs. That's why he left us alone. There is a story. Father told us then when the Channel reached Basarabi, there was a mosque right in the path of where the Channel was supposed to be built and there came an order from those in charge that they should move the mosque out of the way of the project, and that is what they did. The Basarabi mosque is exactly on the edge of the project, 20-30 metres away.... ${ }^{68}$

Thus, although the people faced the incompatibility between life as a factory employee and the practice of the Islam, they felt that this was the result of their own choices within the particular times and economic and social situation, and that it was not at all due to a policy of ethnic and religious assimilation.

By analysing beyond these identity aspects related to language, religious practice, and the relation with the atheist communist regime, we notice that the general tendency of the Turkish Muslim Roma from Medgidia is to discuss how good their life was during the communist regime ${ }^{69}$.

\section{Assimilating the present through the past: now and then}

In the case of older generations, when their youth overlapped with the beginning of the communist regime, the first moment to be recalled is the move from the village to the city, thus placing the period in a positive frame of remembering. The emigration from village to city is remembered as a period of new beginnings, of hopes connected to a new life built thanks to the industrialization and urbanization processes that took place in the 1950s and 1960s, and the possibility to integrate in Medgidia's working-class environment. The simple positive remembrance of the period turns into a nostalgic narration and not only because it discusses the youth of the interlocutors. The opportunity for social mobility, moving upwards from the peasant status to that of member of the working class, with access to the benefits offered by urban life at that point in time, meant a chance for a new life for all interlocutors. In their opinion, it was a better life compared to that lived in villages, a way of life where they found a sense 
and balance of existence, but one that was brusquely interrupted by the fall of communism and the destruction of their urban habitat.

U.L., aged 62, recounts how he moved with his parents to Medgidia when he was 14 . They settled in the apartment of his brother, who worked at IMUM, and U.L. had the opportunity to attend high school after relocating to the city. The IMUM factory is seen as a second home for his family - "we all worked there, mother worked there" - it was the nucleus of urban life, "gone" 70 when the switch to a market economy took place.

51 M.L. recounts how she moved in 1974 from Castelu to Medgidia, alongside her family. She too mentioned the mobility of that period, a result of the migration from the village to the city, and the absorption of the rural population into the city's industrial sector.

My husband worked on the tractor, he was a driver and he no longer wanted to live in the village. We were fed up with the village and when the Channel was built, he was at Basarabi. He went there, he looked for a job, and found one at the Channel. He was hired and he was commuting and it was hard for him and they gave him an apartment, on the other side at IMUM, near the entrance to Medgidia. He was not working at IMUM, but the apartments belonged to the Channel and we lived there for 7-8 years. Afterwards, my husband found a colleague who wanted [to live] at IMUM and I wanted this other side, here at Cement, and we switched apartments. To be closer..., the children went to kindergarten, to school, and there was also my aunt and she helped me sometimes.

Everyone moved away from the countryside. They worked either at Cement, or at IMUM, they were hired at these factories because they no longer wanted to live in the village. They saw that it is harder in the village, that it is better in the city. They bought homes and they all moved here. Before there were no houses here, only plots, and the mayor's office gave the land to build houses. Each factory had several blocks of flats. They had young people moving away from the village who worked there and they had flats. They gave them food, lodging. Now the factory is destroyed, there's nothing left ${ }^{71}$.

L.M., the daughter, believes (like many other Turkish Muslim Roma from Medgidia) that the construction of the Channel was the element that had the greatest influence over people's lives and also over the social, economic, and multi-ethnic character of Medgidia.

The Channel greatly influenced the city. It brought people from all over the country, from engineers to workers, builders, operators.... We have people from Ardeal, there is one at the other block ${ }^{72}$, Mr. Piroska, they all came here because of the construction of the Channel, because there was a lot of work and the people earned money and they gave them houses and that was it... if you come to work in that area, I will give you an apartment ${ }^{73}$.

Although the Danube-Black Sea Channel is generally seen by Romanian society as a typical symbol of the political repression of the communist regime, its construction had a totally different meaning, locally and implicitly, in the Turkish Muslim Roma community from Medgidia. The collective mentality of the local community shares the perception of a prosperous city compared with other cities in Romania, a prosperity granted exclusively by the proximity of the Channel. They consider that the project undertaken by the communist regime - a project that also determined Medgidia's industries and attracted workforce from different parts of the country and determined them to settle in and around Medgidia - opened the way for preferential treatment with regards to how the inhabitants of the city had access to food. 
And it was during Ceaușescu's regime, you couldn't find milk and we went three or four [of us together] in order to buy, we had some connections. We used to grow grapes, apples, seasonal fruits. But we had a good life under Ceaușescu. We heard many horror tales, that you could not find food during communism, here, for example, you couldn't find oil ${ }^{74}$.

...it depends on the area, there were areas where bread was rationed with ration books (at Călărași they used ration books), but not here. We were lucky because of the foreigners who came on the platform and they did not ration bread, oil, but you know... you managed.... ${ }^{75}$ case, the drama of economic hardship is overlapping with an irreversible drama lived alongside her mother and three sisters. In L. M.'s memory, the fall of communism is associated with her father leaving - after being fired from IMUM and failing to obtain a construction job in Bucharest - he went to Belgrade, Serbia in order 
to support the family. He died there, and in the context of the developing Yugoslav wars, the family was marked irreversibly. There was scant information available about her father's death -said to have occurred during a night attack on a group of Muslims but the family was unable to find his body and bring it home, despite the letters sent to the Romanian embassy from Serbia.

The memory of the father is associated with our glorious days, with the emotional fulfilment felt by a united family experiencing economic prosperity. This prosperity was mostly a result of the father's ability to manage and fulfil the daily needs of his family. Thus, in the case of L.M., like in the case of many other children from working families from Medgidia, communism is associated with the best period her family enjoyed, and it was tragically interrupted by the fall of the regime and the arrival of the market economy, democracy, and privatization. These aspects meant for them, however, reaching a low level of poverty, and the break-up of families as parents emigrated to Turkey, the former Yugoslavia and, after 2007, into the European Union, particularly Germany and Spain.

We never suffered from hunger (during communism). It was harder after the revolution, after they lost their jobs. There were years when they cut our electricity, water supply, and not for 2-3 months but for 1-2 years. They (the parents, uncles, and aunts) had to go and work in Turkey, and with the money they sent we ate. I had to go work in the fields with my sisters so that I could earn money to have the house reconnected to electricity and water supply. We were used to having plenty. It was an enormous shock to us, we could not believe our eyes. We had cookies, eggs, milk, beer, Pepsi. I don't know, father brought them from wherever he went. He was a driver on a cement truck and he brought them from where he went. He travelled to Hârșova, Tulcea. He brought us chickens. He put them in the bathroom and we spent all night plucking them. Because he would not cut them a neighbour did, and we put them in the freezer and we had food for the whole week. Plus we have shepherds in the area and they could not raise sheep, flocks of sheep, and they sold them and we sacrificed them. Grandfather knew a shepherd from Călărași, an Aromanian, who also prepared pastrami ${ }^{76}$ and the whole house was filled with pastrami. There were no problems for Kurban. Grandmother prepared jams, compotes.....

61 In other cases, such as that of $\mathrm{H}$., the fall of the socialist system meant that he lost his job at the Cement Factory and had to go through a divorce due to lack money, according to his statements. He was forced to sell his apartment from the city and moved in 2000 to the district of Barăci-Silozuri, on the outskirts of the city. There he rented from the Medgidia City Hall one of the barracks built in the 1950s. The barracks were initially built to house the army corps that worked there during the first phase of the Channel's construction. Now $\mathrm{H}$. is 52 years old and he goes to Spain to beg in order to support his partner, one of his daughters, and an infant grandson ${ }^{78}$.

The lack of solutions to the present-day economic and social problems is in direct contrast with the possibility and the ability offered by the socialist system to find secondary ways for economic survival, through strategies adjacent to the official ones and adapted for each person's daily needs. For the whole society, as in the case of L. M.'s father, these strategies meant building some trade and networks to access certain goods that were very difficult to obtain through official means. In F. S.'s case, work in the fields of G.A.C. meant that she managed to supplement her income by selling full bags she got extra and, in her opinion, helped her to enjoy a decent life. It was enough that she could state that her family "is not crying after communism." 79 
63 At the same time, the alienation ${ }^{80}$ of the working class and the lack of means for professional, economic, and social reconversion led to an identity void and triggered nostalgia for the socialist egalitarianism centred on work. This represents the main source of symbolic and social capital for members of the working class. The work offered them especially a social prestige; it was a source of life and human dignity.

I., who is 83 years old, and who is marked by the daily discipline built around work, considers that work represented the main coordinate of his life. It is this discipline that helped him lead an organized life, without vices, and to sustain the strict schedule imposed by his job as a driver at I.R.T.A. Medgidia (Regional Public Transport Company, Medgidia). Although he admits that it was a hard life, he considers that he had a welldefined role in society, and that it was preferable to his early retirement in 1990-1991. Because his pension was calculated according to his base salary, without taking into account the extra hours he worked at the Channel as a truck driver, he endured financial hardships and was forced to continue working as a driver after retirement. He worked for a very small salary for a small entrepreneur who owned a business and traded in alcohol and food ${ }^{81}$.

\section{Conclusions}

Given the specific objective of my research, to explore the intersection between memory and identity, the conclusions drawn based on the interviews affirm Svetlana Boym's hypothesis that nostalgia is related to present needs and to desires of the future. It is an attempt to overcome the sense of personal and collective humiliation and to regain authenticity in the era of capitalism.

My interlocutors deplore the fact that work has lost its value, being replaced by simple material gain, and by money that can buy any goods from what is available. Money thus became the main value in post-communist society and the main indicator of one's social status, deeply influencing even social connections. The authenticity of relations prior to 1989 represents the greatest loss in the opinion of the interlocutors; it puts in contrast the individuality of the capitalist society with a certain respect and joy of being together.

The abundance of the market economy post-1990 seems to be somewhat useless to them given their new status as unemployed. The freedom of information brought on by the fall of the communist regime is for them the proverbial Pandora's box. Unemployment got out, a concept they did not know the meaning of until then, with everything that comes along with it: poverty, loss of homes, emigration. All this now regulates their lives in the most profound and personal way. Given the context, their own ethnicity and Muslim religious belief have become the main identity cores of the Turkish Muslim Roma immediately after 1990. The city is affected by a process of deindustrialization, along with social and economic decay, and the Turkish Muslim Roma represent first of all the former working class of Medgidia. Now, as they are unemployed or went into early retirement, a part of the Turkish Muslim Roma is more preoccupied with rebuilding their social dignity and identity. Sometimes they have found solutions, such as being employed in the few jobs available in local administration, at public spaces, in the hospital, with small local entrepreneurs, as salesmen in grocery stores, in the local bazaar, as carpenters, or as seasonal workers in 
the fruit farms around Medgidia. Sometimes they have emigrated temporarily in Turkey, former Yugoslavia and after 2007 in Germany, Spain or England.

Ethnicity and religion have become attenuated in this rhythm of life. They are aprioristic data, accepted because of tradition and previous generations. The distance from ethnic and religious identity that resulted from relations established in socialism has been maintained in many ways ${ }^{82}$. But the loss of the symbolic capital of work in the post-1990 period led to a reshuffle towards ethnicity and religion, in a complex process which intertwines the migrations towards the West, the general frame of rediscovery of ethnic identity by the Turkish community, and the creation of the Turkish Democratic Union. After 1990 these factors became a new source for social prestige and implicitly social identity.

Before 1989, the atheist policy of the communist regime and modernization in the socialist sense with all the processes involved: the emigration from the village to the city, the employment in the industrial sector and the integration in the working class from the economic and social point of view, led to a secularization of the community in the broader context of socialist society, in the sense of the displacement of religion from the public space ${ }^{83}$.

The consequence in time has been the attenuation of religious practice or the individualization and internalization of the faith, whose only manifestation space has remained the private one. For example, L.M. testifies that her father prayed mostly in private, reading the prayer books brought from Turkey ${ }^{84}$, while F.ș. says he did not have time for religion, attending the mosque only on the occasion of the two great holidays, Kurban Bayram and Ramazan Bayram ${ }^{85}$.

71 These were the only religious festivals observed at the community level in the communist period. The observance of the two festivals had certain limitations. For instance, the fast, which precedes the Ramazan Bayram, represented, as the interviewees state, almost exclusively the preoccupation of the elderly. Insofar as Kurban Bayram was concerned, the festival was observed by visiting parents, grandparents, or relatives.

72 At the same time, weddings, circumcision ceremonies, and funerals, organized according to the Islamic tradition, represented during the communist years, the main reunion occasions for the community. These, along with Turkish language as it was spoken in the family, especially through their mothers, inspired them with an ethnic and religious peculiarity in the socialist society, but did not stop the process of blurring and distancing ethnic and religious identity.

73 Attracted by the advantages of urban life and those that resulted from belonging to the working class, such as a fixed salary, lodging, and social mobility, motivated the desire for social adaptation and a social attachment centred around work.

In conclusion, I can say that exploring memory among working-class members of the Turkish Roma Muslim community in Medgidia, and by using the concept of reflective nostalgia (which dwells on the ambivalences of human longing and belonging), we have revealed a micro-process of social and symbolic reclassification by a social group and ethnic subgroup, in the post-socialist era, often characterized by the traumatic challenges specific for the transition to the market economy. 


\section{NOTES}

1. GAGNON J. H., "The self, its voices, and their discord," in C. Ellis, M. Flaherty (eds.), Investigating Subjectivity, Newbury Park, CA, Sage, 1992; HOLSTEIN J. A., GUBRIUM J. F., The self we live by: Narrative identity in a postmodern world, New York, Oxford University Press, 2000, p. 221-244.

2. KANEVA Nadia, "Memories of Everyday Life in Communist Bulgaria: Negotiating Identity in Immigrant Narratives", Colorado Research in Linguistics, Vol. 19, no. 1, 2006, http:// www.colorado.edu/linguistics/CRIL/Volume19_Issue1/ (accessed in December 2017).

3. HALBWACHS Maurice, On collective memory, Chicago, The University of Chicago Press, 1992, p. 182.

4. Todorova Maria, GILle Zsuzsa (eds.), Post-Communist nostalgia, Oxford, New York, Berghahn Books, 2010.

5. BoYm Svetlana, The future of nostalgia, New York, Basic Books, 2001.

6. Svetlana Boym introduces "a distinction between restorative and reflective nostalgia to differentiate between national and social memory. In her reading, restorative nostalgia does not think of itself as nostalgia, but rather as truth and tradition. Reflective nostalgia dwells on the ambivalences of human longing and belonging, and does not shy away from the contradictions of modernity. Restorative nostalgia protects the absolute truth, while reflective nostalgia calls it into doubt. Restorative nostalgia is at the core of recent national and religious revivals. It knows two main plots-the return to origins and conspiracy. Reflective nostalgia does not follow a single plot but explores ways of inhabiting many places at once and imagining different time zones. It loves details, not symbols. At best, it can present an ethical and creative challenge, not merely a pretext for midnight melancholies. If restorative nostalgia ends up reconstructing emblems and rituals of home and homeland in an attempt to conquer and specialize time, reflective nostalgia cherishes shattered fragments of memory and demoralizes space. Restorative nostalgia takes itself dead seriously. Reflective nostalgia, on the other hand, can be ironic and humorous. It reveals that longing and critical thinking are not opposed to one another, just as affective memories do not absolve one from compassion, judgment, or critical reflection." For a broader discussion on this subject ibid., p. 41-56.

7. TODOROVA, GILLE (eds.), Post-Communist nostalgia, op. cit., p. 286.

8. PASSERINI Luisa, Fascism in popular Memory. The cultural experience of the Turin working class, Cambridge, Cambridge University Press, 1987.

9. MASSINO Jill, "Something Old, Something New: Marital Roles and Relations in State Socialist Romania," Journal of Women's History, Vol. 22, no. 1, 2010, p. 36.

10. GEORGESCU Diana, “Ceaușescu hasn't died: Irony as countermemory in post-socialist Romania," in Maria Todorova, Zsuzsa Gille (eds.), Post-communist nostalgia, Oxford, New York, Berghahn Books, 2010, p. 155-176.

11. IORDACHI Constantin, "Citizenship, Nation and State-Building: The Integration of Northern Dobrogea into Romania (1878-1913)," The Carl Beck Papers in Russian \& East European Studies (University of Pittsburgh), no. 1607, 2002, p. 7-8.

12. OPRIȘAN Ana, GRIGORE George, "The Muslim Gypsies in Romania," ISIM Newsletter, no. 8, 1999, p. 32; ISAC ALAK Alina, "Types of Religious Identities within Romanian Muslim Communities," Journal for the Study of Religions and Ideologies, Vol. 14, no. 41, 2015, p. 148-173; MARUSHIAKOVA Elena, POPOV Vesselin, Roma Muslims in the Balkans. Project Education of Roma Children in Europe, online: http:// romafacts.uni-graz.at/index.php/culture/introduction/roma-muslims-in-the-balkans (accessed in December 2017).

13. MARUSHIAKOVA Elena, POPOV Vesselin, "Identity and language of the Roma in Central and Eastern Europe," in Tomasz Kamusella, Motoki Nomachi, Catherine Gibson (eds.), The Palgrave 
handbook of Slavic languages, identities, and borders, New York, Palgrave Macmillan, 2016, p. 28. It has to be noted in this context that Muslim identities across the Balkans reflect similar, but not identical, patterns of overlap. For example, the situation of the Pomaks in Bulgaria who are, as defined by Hugh Poulton, a people of Slavic (Bulgarian) origin who speak Bulgarian as their mother tongue but whose religion and customs are Islamic. Although the word Pomak has negative connotations, Pomak (Pomaci), or Bulgarian Mahomedans (Bulgaro-Moxamedani, Bulgaromoxamedani) are the most frequently used ascriptive designations by scholars and journalists. Kamen Burov, the founder of a Pomak party in 1993, the Democratic Labour Party, in an attempt to free the word Pomak from its negative connotations, has lobbied for the recognition of a Pomak ethnic minority in Bulgaria. To date, his party and his ideas have gained few followers among the Pomak population. Most Pomaks prefer Mohamedans (Moxamedani) or Muslims (Mjuslumani) as self-ascriptive terms. However, there is no consensus on these terms either. Depending on the situation, they may identify themselves as Pomaks, Muslims, Bulgarians, Turks. See EmINov Ali, "Social Construction of Identities: Pomaks in Bulgaria," Journal on Ethnopolitics and Minority Issues in Europe, Vol. 6, no. 2, 2007, p. 6. 19rought from Turkey, while F.Șage, spoken in the family they spoke it a lot in teh ta desfășurării workshop-ului.

14. Ibid., p. 27.

15. The war of 1877-1878 caused a considerable Muslim emigration from the province, estimated at 90,000 people. The figures relating to the Muslim population differ substantially; some authors estimate 134,662 Muslims and 87,900 Christians in Dobruja in 1879, while others account for 56,000 Muslims and 54,726 Christians. Another source, counting intermediary emigrations, gives 48,784 Turks for 1878. KARPAT Kemal, "Urbanismul ottoman: emigraȚia din Crimeea spre Dobrogea și întemeierea orașului Medgidia (1856-1878)" [Ottoman Urbanism: Emigration from Crimea to Dobruja and the foundation of Medgidia], in TAHSIN Gemil (ed.), Tătarii în istorie și în lume, Bucharest, Kriterion, 2003, p. 209-230.

According to official Romanian sources, in 1879 the most numerous ethnic groups in 1879 were Turks and Tatars who numbered together 32,033 while the Romanians registered at 31,177 and the Bulgarians at 28,715 , out of a total of 106,943 . See IORDACHI, "Citizenship, Nation and StateBuilding," op. cit. p. 8.

16. BARA Maria, "Relaţii interetnice dintre creştinii ortodocşi şi musulmani în Dobrogea. Studiu de caz: Medgidia şi Cobadin" [Interethnic relations between Christian Orthodox and Muslims in Dobruja. Case study: Medgidia and Cobadin], Philologica Jassyensia, Vol. II, no. 1, 2006, p. 95; SCHMIDT-RÖSLER Andrea, "Dobrudscha," in Michael Weithman (ed.), Der ruhelose Balkan. Die Konfliktregionen Südosteuropas, München, Deutscher Taschenbuch Verlag, 1993, p. 101.

17. The Settlement Law (Iskan Kanunu) in 1934 specifies that only those who are of Turkish descent and culture could emigrate and settle in Turkey. The law gave authority to the Council of Ministers to decide who qualifies for belonging in terms of Turkish ethnicity and culture, and Muslims were considered eligible for these criteria. Accordingly, this law benefited ethnic Albanians, Bosnians, Circassians, South Africans, and Tatars, as well as Turks. See AKGÜNDÜZ Ahmet, "Migration to and from Turkey, 1783-1960: types, numbers and ethnoreligious dimensions," Journal of Ethnic and Migration Studies, Vol. 24, no. 1, 1998, p. 112.

18. KOLUKIRIK Suat, "Perceptions of identity amongst the Tarlabasi Gypsies," in Adrian Marsh, Elin Strand (eds.), Gypsies and the problem of identities: Contextual, constructed, and contested, Istanbul, Swedish Research Institute, 2006, p. 134.

19. National Institute of Statistics, "Population and housing census, 18-27 March 2002," in Vol. IV, Ethnic and confessional distribution. Population according to ethnicity between 1930 and 2002 according to counties, online: http://www.insse.ro/cms/files/RPL2002INS/vo4/tabele/t2.pdf (accessed in December 2017).

20. Ibid. 
21. National Institute of Statistics, "Stable population by ethnicity and mother tongue, by categories of habitation," Romanian Census 2011, online: http://www.recensamantromania.ro/ rezultate-2/ (accessed in January 2018).

22. Population-Demographic structure, the population and housing census of January 5, 1977, Vol. 1-2, Bucharest, General Direction of Statistics, 1980.

23. National Institute of Statistics, "Stable population by ethnicity and religion," Romanian Census 2011, online: http://www.recensamantromania.ro/rezultate-2/ (accessed in January 2018).

24. Population-Demographic structure, op. cit.

25. National Institute of Statistics, "Stable population by ethnicity and religion," op. cit.

26. KARPAT, “Urbanismul ottoman”, op. cit., p. 209-231.

27. Ibid.

28. URSU Nicolina, "Turco-tătarii dobrogeni în recensăminte și statistici românești (1878-1916)" [Dobruja Turk-Tatars in Romanian census and statistics], in Tahsin Gemil (ed.), Tătarii în istorie și in lume, op. cit., p. 307-312.

29. Population by nationalities 1930-1992, Demographic data provided by the ConstanȚa County Statistical Department, May 10, 2018.

30. Ibid.

31. HERBST RĂDOI Atena, “Aspecte geografice în dezvoltarea orașelor din Dobrogea, cu privire specială asupra zonei litorale" [Geographical aspects regarding the development of Dobruja towns, a special analysis of the coastal area], Studii și cercetări de geologie, geofizică, geografie, Vol. 12, no. 2, 1965, p. 288.

32. ILIE Adrian, Medgidia. Istoria orașului de la 1918 până în prezent [Medgidia. The history of the town since 1918 until the present], ConstanȚa, Ex Ponto, 2012, p. 129.

33. Ibid.

34. Ibid., p. 127.

35. Ibid., p. 123.

36. "Population by ethnicity and mother tongue. ConstanȚa County, Medgidia Municipality," Population and Housing Census (2002) ConstanȚa County Statistical Department.

37. "Population by ethnicity. ConstanȚa County, Medgidia Municipality," Population and Housing Census (2011), ConstanȚa County Statistical Department. untyidia municipality, CoȚii cu hereknow, e communism....ca membru, pe anul calendaristic 2018. Pentru mai multe informaȚii $\mathrm{cu}$

38. The archive funds consulted are: General Directorate of the Danube-Black Sea Channel Fund, Headquarters of the Danube-Black Sea Channel Fund, Medgidia District People's Council Fund, and Medgidia City Hall Fund.

39. In the field can be detected some specific male Turkish names which are used only within the Turkish Muslim Roma community, as for example șaban or Riza. These names reflect both an ethnic and religious affiliation.

40. Headquarters of the Danube-Black Sea Channel Fund, 1/1983, f. 40.

41. Ibid., f. 416.

42. Ibid., f. 131.

43. Ibid., f. 370.

44. Mental or cognitive mapping is the product of a series of psychological processes that register, code, store, then call to mind and decode all information on our everyday spatial environment. When a researcher does mental mapping, he is actually interested in mapping maps, that is collecting and interpreting mental maps from our minds. See: DowNS Roger, STEA David, Maps in minds. Reflections on cognitive mapping, New York, Harper \& Row, 1977, p. 15.

45. EmINov Ali, “Turks and Tatars in Bulgaria," Nationalities Papers, Vol. 28, no. 1, 2000, p. 140-143. 
46. The two great Islamic holidays, Kurban Bayram and Ramazan Bayram (for more explanation see below).

47. Interview with S., Medgidia, ConstanȚa County, October 19, 2015.

48. Interview with L. M., Medgidia, ConstanȚa County, October 19, 2015.

49. Interview with U. L., Medgidia, ConstanȚa County, October 12, 2015.

50. Interview with M. L., Medgidia, ConstanȚa County, October 19, 2015.

51. Interview with S. A., Medgidia, ConstanȚa County, October 22, 2015.

52. Băneasa became a town after the fall of the communism.

53. Interview with I. B., Medgidia, ConstanȚa County, October 19, 2015.

54. Interview with S. I., Medgidia, ConstanȚa County, October 20, 2015; Interview with F. Ș., Medgidia, ConstanȚa County, October 20, 2015

55. Interview with H., Medgidia, ConstanȚa County, June 11, 2015. For an exact geographic location of the villages and of the migratory movement see Figure 1. Dobruja - The Frontier Zone Romania-Bulgaria.

56. See RONNAS Per, Urbanization in Romania. A geography of social and economic change since independence, The Economic Research Institute at Stockholm School of Economics, 1984; Federal Research Division, Romania, country study, Kessinger Publishing, 2004, p. 91.

57. Interview with U. L., Medgidia, ConstanȚa County, October 12, 2015.

58. Ibidem.

59. FLOREA Elena, Principiile politicii PCR in problema naȚională [Principles of PCR Politics in the national problem], Bucharest, Editura Politică, 1975, p. 82-83.

60. Interview with M. L., Medgidia, ConstanȚa County, October 19, 2015.

61. Interview with L. M., Medgidia, ConstanŢa County, October 19, 2015.

62. LEMENI Adrian, ViaȚa religioasă în România [Religious life in Romania], Bucharest, Editura Bizantină, 2005, p. 11

63. TURNER Bryan, "Islam, public religion, and the secularization debate," in Gabriele Marancci (ed.), Muslim societies and the challenge of secularization. An interdisciplinary approach, Dordrecht, Springer, 2010, p. 11-31.

64. Kurban Bayram (Feast of the Sacrifice) is an homage paid to Prophet Ibrahim who - forced to choose between his own son and his adoration of Allah - chooses the latter. As a reward, Allah sends him a ram to be sacrificed instead of the son who will live. The sacrifice of the ram, whose meat is divided in three parts: for the family, for friends and for neighbours, and for the poor is a traditional obligation for the Muslim who is economically independent and has financial means. The obligation strengthens the relations inside and in-between communities, amplifying the feelings of solidarity. After the Bayram prayer (Bayram Namazî) - a prayer that is mandatory to be made in mosques - the men go to the houses of those who died during the course of the year, and there they read the Quran. Afterwards follow four days of relaxation with traditional feasts and visits to the parents, grandparents, relatives, and friends, thus strengthening the family and the community. See IBRAM Nuredin, Comunitatea musulmană din Dobrogea [The Dobruja Muslim community], ConstanȚa, Ex Ponto, 2011, p. 55.

65. The Ramazan Bayram Feast (Fasting Feast, Fast of the Sweets) is, alongside Kurban Bayram, the second important religious feast of the Muslim religion. It is a time for strengthening and consolidating the Turkish community. The month of fasting (30 days) is designed to fortify physically and mentally and ends with the Bayram prayer (Bayram Namazî). It is followed by three days of joy, relaxation, and reconciliation. Ibid.

66. The concept of domestication of religion is used for the USSR case by DRAGADZE Tamara, in "The domestication of religion under Soviet communism," in Chris M. Hann (ed.), Socialism: Ideals, ideologies, and local practice, London, Routledge, 1993, p. 144.

67. Interview with M. L., Medgidia, ConstanŢa County, October 19, 2015. 
68. Interview with L. M., Medgidia, Constanţa County, October 19, 2015.

69. In Kideckel's opinion, under the post-socialist pressures, workers ignore the shortcomings of the socialist past and remember, for example, the resources provided, social collectivity, shared commitment at work, mobility, and the security of one's job and material life. See KIDECKEL David, România postsocialistă. Munca, trupul și cultura clasei muncitoare [Post-socialist Romania: Labour, the body, and working-class culture], Iași, Polirom Publishing House, 2010.

70. Interview with L. M, Medgidia, Constanţa County, June 12, 2015.

71. Interview with M. L., Medgidia, Constanţa County, October 19, 2015.

72. Residential building.

73. Interview with L. M, Medgidia, Constanţa County, June 12, 2015.

74. Ibid.

75. Interview with M. L., Medgidia, ConstanŢa County, October 12, 2015.

76. Pastrami is a meat product usually made from beef or sheep.

77. Interview with M. L., Medgidia, ConstanŢa County, October 19, 2015.

78. Interview with H., Medgidia, Constanţa County, June 11, 2015.

79. Interview with F. S., Medgidia, Constanţa County, October 19, 2015.

80. I used the term alienation in the sense of estrangement, loss of belonging to a social class, and implicitly the class's loss of its own place in society. I took over the term from David Kideckel, in whose view the phenomenon of alienation of the working class, based on his fieldwork in Valea Jiului (Romania), means the estrangement of people in their own skin (p. 167-193). The author concludes that the gender identity (for men and women as well) is affected, undermined, and reformulated in content and meaning by the specific socio-economic forces. See KIDECKEL, România Postsocialistă, op. cit.

81. Interview with I., Medgidia, ConstanŢa County, October 20, 2015.

82. Based on her fieldwork in Bulgaria, Kristen Ghodsee analyses the possibility for a religious identity without spiritual commitment. For more on this topic, see GHODSEE Kristen, "Minarets after Marx. Islam Communist Nostalgia and the Common Good in Postsocialist Bulgaria," East European Politics and Societies, Vol. 24, no. 4, 2010, p. 520-542, here p. 528.

83. See DRAGADZE, op. cit., p. 144.

84. Interview with L.M., Medgidia, Constanţa county, October 19, 2015.

85. Interview with F.Ș., Medgidia, Constanţa county, October 20, 2015.

\section{ABSTRACTS}

My research is part of a direction regarding the current situation of the Turkish Muslim Roma in the national states from the Balkans, created after the fall of the Ottoman Empire, and it is putting forward the description of a Muslim Roma Turkish-speaking community in a postsocialist city in the south-eastern part of Dobruja, Medgidia (Mecidiye). The specific objective of the research is to explore the intersection between memory and identity and to attempt to identify the way in which the political, economic and social changes of the communist period were reflected in the ethnic and religious identity structure of the Turkish Muslim Roma community of Medgidia. Exploring the memory of communism, life histories led our research towards the perspective of nostalgia, understood as a type of memory, a re-creation of the past 
that goes beyond the mere recovery, reaching political, ideological, socio-economic and personal dimensions related also to the present needs and to desires of the future.

Ma recherche s'inscrit dans une perspective sur la situation actuelle des Roms musulmans dans les États nationaux des Balkans créés après la chute de l'Empire ottoman. Je propose de décrire une communauté de Roms musulmans de langue turque dans une ville située dans la partie sudest de la Dobrudja, Medgidia (Mecidiye), à l'époque postcommuniste. Mon objectif est d'explorer l'articulation entre la mémoire et l'identité et d'essayer d'identifier la façon dont les changements politiques, économiques et sociaux de la période communiste se reflètent dans la structure identitaire ethnique et religieuse de la communauté des Roms musulmans de Medgidia. Cette exploration de la mémoire du communisme par l'intermédiaire des récits de vie a orienté ma réflexion vers la perspective de la nostalgie, comprise comme un type de mémoire et comme une recréation du passé qui dépasse le simple repli sur le passé pour atteindre des dimensions politiques, idéologiques, socioéconomiques et personnelles liées aussi aux besoins présents et aux désirs du futur.

\section{INDEX}

Geographical index: Roumanie, Dobroudja

Keywords: Turkish Muslim Roma, Dobruja (Romania), identity, memory, nostalgia

Mots-clés: Roms musulmans turcophones, Dobrudja (Roumanie), identité, mémoire, nostalgie

\section{AUTHOR}

\section{ADRIANA CUPCEA}

Romanian Institute for Research on National Minorities, adriana.tamasan[at]gmail.com 